\title{
Cell wall surface properties and flocculence of a Kluyveromyces marxianus strain
}

\author{
J.A. Teixeira *, R. Oliveira, J. Azeredo, M. Sousa, C. Sil \\ Universidade do Minho, Centro de Engenharia Biológica, Campus de Gualtar 4709, Braga Codex. Portugal
}

Received 26 January 1995; accepted 30 May 1995

\begin{abstract}
Yeast flocculation is under genetic control and is described as a cell wall interaction. This characteristic of yeast cells has been traditionally used in industrial fermentation processes. The surface characteristics of the cell walls are expected to be a determinant factor in the aggregation mechanism. Results confirming this have been reported for Saccharomyces strains. It is important to extend these studies to other genera. Among them, due to its potential industrial interest, Kluvveromyces strains must be considered. In this work are reported results relating cell wall surface properties (hydrophobicity and electrophoretic mobility) with the flocculation ability of a strain of Kluyveromyces marxiants. The effect of proteolytic enzymes, $\mathrm{pH}$, salts and sugars on flocculation was also studied. The results obtained clearly demonstrate that cell wall hydrophobicity is a major determinant in the flocculation ability of the Kluyeromyces marxianus cells.
\end{abstract}

Keywords: Cell wall surface; Electrophoretic mobility; Flocculation; Hydrophobicity; Klyuceromyces marxianus; Flocculation ability

\section{Introduction}

Flocculation in yeasts is usually defined as the ability of cells to aggregate spontaneously and form flocs which sediment rapidly in culture medium [1]. This capacity of yeast cells has been traditionally utilized by the brewing and wine industries and, more recently, in continuous ethanolic fermentation processes. By allowing an increase in the biomass concentration in the bioreactor or by facilitating downstream processing, the flocculation ability of yeasts may be an important factor in the overall performance of the process.

So far, the main studies on yeast flocculation only report results obtained with Saccharomyces

* Corresponding author. strains. Few deal with flocculent yeasts belonging to other genera.

Yeast flocculation is under genetic control and is described as a cell wall interaction $[2,3]$. The lectin-like model proposed by Miki et al. [2] is generally accepted. In this model, a specific lectinlike component present in the cell wall of the flocculent strain will recognize and adhere to $x$ mannans carbohydrates on an adjoining cell, with $\mathrm{Ca}^{2+}$ ions acting as cofactors activating the binding capacity.

Some important features of flocculation of Saccharomyces strains have been identified: calcium is required for flocculation $[4,5]$, flocculation is inhibited specifically by sugars, namely mannose and mannose derivatives [6,7]. nonflocculent cells can interact with flocculent cells [8], and flocculation is shown to be affected by 
cultural conditions [9]. It has also become clear that hydrophobic interactions play a crucial role in microbial adhesion phenomena $[8,10,11]$. Several studies have been presented dealing with the relationship between cell surface hydrophobicity and yeast flocculation. All the studies, as previously mentioned, using Saccharomyces strains, indicate that an increase in flocculence is strongly correlated with an increase in cell surface hydrophobicity. Surface charges may also be expected to play a role in flocculation. However, no correlation has been found between flocculation and zeta potential for bottom fermenting Saccharomyces strains $[11,12]$.

Since flocculation experiments have been centered in Saccharomyces strains, it is important to extend flocculation studies to other genera. Kluyveromyces, due to its potential in fermenting lactose for cheese whey recovery, is a species of industrial interest [13]. Teixeira et al. [14] described the utilization of the Kluyveromyces strain under study for the ethanolic fermentation of lactose in high cell density continuous systems.

Reported results for a Kluyveromyces strain indicate that, as for Saccharomyces strains, a cell wall protein is involved in the flocculation mechanism $[15,16]$. Also, it has been shown that the structure and/or spatial arrangement of the cell wall groups involved in flocculation is not the same in $K$. marxianus and S. cerevisiae [17].

In this work, the characterization of surface properties (electric charge and hydrophobicity) of yeast cells of a Kluyveromyces strain and its involvement in flocculation are discussed.

\section{Material and methods}

\subsection{Yeast strain and culture conditions}

The yeast strain investigated in this study was Kluyveromyces marxianus (ATCC 10022 ).

Flocculation was induced in a continuous bioreactor as described by Mota and Teixeira [18]. It was necessary to use this methodology, since no flocculation occurs when the cells are grown in a batch bioreactor.

In all experiments (either batch or continuous) the culture medium had the following composition, per liter of tap water: lactose, $50 \mathrm{~g} ; \mathrm{KH}_{2} \mathrm{PO}_{4}, 5 \mathrm{~g}$; $\left(\mathrm{NH}_{4}\right)_{2} \mathrm{SO}_{4}, 2 \mathrm{~g} ; \mathrm{MgSO}_{4} \cdot 7 \mathrm{H}_{2} \mathrm{O}, 0.4 \mathrm{~g}$; yeast extract, $1 \mathrm{~g}$.

\subsection{Surface charge}

The surface charge was measured as the electrophoretic mobility in a Zeta-meter system $3.0+$ (Zeta-meter Inc., New York).

The zeta potential was measured in $5 \mathrm{mM}$ phosphate-buffered saline (PBS) at different values of the $\mathrm{pH}(3,4,5,6)$ obtained by the addition of $\mathrm{HCl}$.

Prior to the measurements, the yeast cells were thoroughly washed with deionized water and resuspended in each $\mathrm{pH}$ solution to a final absorbance value of 0.8 , measured at $620 \mathrm{~nm}\left(A_{620}\right)$.

The results expressed in millivolts are the average of 20 measurements.

\subsection{Flocculation assay}

To measure the flocculation ability of Kluyveromyces marxianus, the yeast cells were washed with deionized water and resuspended in the flocculation buffer $(50 \mathrm{mM}$ acetate buffer ( $\mathrm{pH} 4.0$ ) with $1 \mathrm{mM} \mathrm{CaCl}$ ) to a final $A_{620}$ value of 2.0 .

A $700 \mu \mathrm{l}$ portion of this cell suspension was added to a $1 \mathrm{ml}$ cuvette and whirl-mixed for $20 \mathrm{~s}$, followed by five inversions of the cuvette immediately after mixing. The measurement of the flocculation ability of the cells corresponds to the maximum rate of decrease in optical density (OD) per minute $(\Delta \mathrm{OD} / \Delta t)[7]$. The values obtained for the flocculation ability represent the mean of 5-10 experiments and are affected by an error that is not higher than $10 \%$.

\subsection{Determination of cell surface hydrophobicity}

The cell surface hydrophobicity was measured by three different techniques: interaction of yeast cells with hexadecane, phase partition and hydrophobic interaction chromatography. 


\subsubsection{Interaction of yeast cells with hexadecane}

The assay involving the interaction of yeast cells with the hexadecane was based on the method described by Rosenberg for bacteria [19]. In this procedure, $1 \mathrm{ml}$ of $n$-hexadecane was added to $4 \mathrm{ml}$ of washed yeast cells resuspended in the flocculation buffer to a final $A_{620}$ value of 2.0. This mixture was then vortexed during $60 \mathrm{~s}$, with a $5 \mathrm{~s}$ pause after the first mixing period of $30 \mathrm{~s}$. The two phases were allowed to separate for $5 \mathrm{~min}$.

The percentage of adhered cells was determined by the decrease in the absorbance value of the lower aqueous phase measured at $620 \mathrm{~nm}$. The data were expressed as

$\%$ Adhesion $=\frac{\left(A_{620} \text { initial }-A_{620} \text { final }\right)}{A_{620} \text { initial }}$

\subsubsection{Phase partition}

Phase partition was performed in a biphasic aqueous mixture of poly(ethylene glycol) and dextran T500 [20].

The biphasic system with an interfacial tension

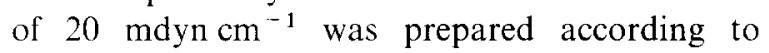
Gerson [20].

This solution was whirl-mixed with $3.0 \mathrm{~g}$ (expressed as dry weight) of washed cells. The emulsion formed was allowed to settle by gravity for $2 \mathrm{~h}$ and then centrifuged at $200 \mathrm{rev} \mathrm{min}^{-1}$ for $15 \mathrm{~min}$.

Samples were taken from both the light and the dense phase, and cell concentrations were determined in a Neubauer chamber.

The data were expressed as partition index (PI), defined as the ratio between the cell concentration in the light and the dense phases.

\subsubsection{Hydrophobic interaction chromatography ( $\mathrm{HIC}$ )}

HIC was based on the method described by Clark et al. [21], with sepharose-CL-4B (the nonhydrophobic control) and octyl sepharose-CL-4B.

HIC was performed in two burettes of $15 \mathrm{ml}$ plugged with glass wool and containing $3 \mathrm{ml}$ of either type of sepharose. The columns were washed extensively and equilibrated with acetate buffer ( $\mathrm{pH} 4.0$ ). To each column were applied $2.5 \mathrm{ml}$ of washed yeast cells resuspended in flocculation buffer to a final $A_{620}$ value of 2.0 .

The percentage of cells eluted from the columns was determined by reading the absorbance of the eluted samples at $620 \mathrm{~nm}$. The data were expressed as the hydrophobic index ( $\mathrm{HI})$, defined as

$\mathrm{HI}=\frac{(\% \text { Control eluted }-\% \text { Octyl eluted })}{\% \text { Control eluted }}$

\subsection{Treatment of flocculent yeast cells}

Flocculent yeast cells were treated with a proteolytic enzyme, sugars, salts and by changing the $\mathrm{pH}$, according to the following procedures.

\subsubsection{Proteolytic enzyme}

The yeast cells were washed and resuspended in a solution of $\mathrm{HCl}(\mathrm{pH} 2.0)$ containing $1.92 \mathrm{~g} \mathrm{l}^{-1}$ of pepsin to a final $A_{620}$ value of 2.3 .

The cell suspensions were incubated for 10,30 and $60 \mathrm{~min}$ at $37^{\circ} \mathrm{C}$ under gentle agitation.

The yeast cells were then washed three times with deionized water and resuspended in the flocculation buffer to a final $A_{620}$ value of 2.0 .

A control was prepared for flocculent yeast cells without pepsin.

\subsubsection{Sugars}

The yeast cells were treated with mannose $(10$, $25,50,100,200 \mathrm{mM})$, glucose $(50,100,200 \mathrm{mM})$ and lactose $\left(50,100,200 \mathrm{~g}^{-1}\right)$.

The flocculent yeast cells were washed and resuspended in the flocculation buffer containing the above-mentioned sugars to a final $A_{620}$ value of 2.3 .

The suspension was incubated for $40 \mathrm{~min}$ at room temperature under gentle agitation.

The yeast cells were then washed three times with deionized water and resuspended in the flocculation buffer to a final $A_{620}$ value of 2.0 .

The controls were incubated with the flocculation buffer only.

\subsubsection{Salts}

Yeast cells were washed and resuspended in acetate buffer ( $50 \mathrm{mM}$; pH 4.0 ) containing $\mathrm{CaCl}_{2}$ and $\mathrm{NaCl}$ to a final $A_{620}$ value of 2.3 . 
The suspension was incubated for $40 \mathrm{~min}$ at room temperature under gentle agitation.

The cells were then washed three times with deionized water and resuspended in flocculation buffer to a final $A_{620}$ value of 2.0 .

Controls were incubated with acetate buffer only.

\subsection{4. $p H$}

A series of solutions with $\mathrm{pH}$ values in the range 3.0-6.0 was prepared with acetate buffer.

Yeast cells were washed and resuspended in each solution to a final $A_{620}$ value of 2.3 .

The suspension was incubated for $40 \mathrm{~min}$ at room temperature under gentle agitation.

The cells were then washed three times with deionized water and resuspended in the flocculation buffer to a final $A_{620}$ value of 2.0 .

\section{Results and discussion}

As a first attempt, the measurement of contact angles was tried as the hydrophobicity assay to be used. Although the procedure described by Busscher et al. [22] was followed closely, it was not possible to obtain reasonable contact angles. The penetration of the water drop into the cell lawn was so fast that in most of the cases it was impossible to make the measurement. Other investigators have reported a similar experience [23].

To solve this problem, it was decided to use hydrophobicity tests based on the measurement of actual binding to a hydrophobic ligand, such as hexadecane, octyl-sepharose and poly(ethylene glycol), because their similarity would anticipate a good correlation.

Table 1 summarizes the results obtained for all the hydrophobicity assays.

Comparing the results, a good correlation is observed between the three methods. This seems to be in agreement with published comparisons of various cell surface hydrophobicity tests [24].

As has been suggested, even presumably similar tests measure essentially different properties [23]. It is not possible to measure the absolute surface hydrophobicity of a cell, but using the same
Table 1

Hydrophobicity of the cell walls of flocculent ${ }^{\mathrm{a}}$ and nonflocculen $t^{b}$ yeast strains of Kluyveromyces marxianus, using three different assays

\begin{tabular}{lll}
\hline $\begin{array}{l}\text { Type of } \\
\text { data obtained }\end{array}$ & $\begin{array}{l}\text { Flocculent } \\
\text { strain }\end{array}$ & $\begin{array}{l}\text { Non-flocculent } \\
\text { strain }\end{array}$ \\
\hline Adhesion & 20 & 11 \\
HI & 0.84 & 0.65 \\
PI & 0.052 & 0.023 \\
\hline
\end{tabular}

${ }^{a}$ Grown in a continuous system.

${ }^{\mathrm{b}}$ Grown in a batch system.

${ }^{c}$ Relating to the three assay methods.

method it is possible to obtain values that can be used on a comparative level.

An important result expressed in Table 1 is that all the tests assayed for measuring cell wall hydrophobicity clearly show that the hydrophobicity is higher for flocculent cells than for non- flocculent cells of $K$. marxianus. These data are a first indication that cell surface hydrophobicity may be a determinant factor in the flocculation mechanism of this strain. These results are similar to those reported for Saccharomyces strains $[8,10,11]$.

It is known that the ability of cells to flocculate is dependent on factors such as the $\mathrm{pH}$, sugar concentration, divalent ion concentration (namely $\mathrm{Ca}^{2+}$ ) and monovalent ion concentration $\left(\mathrm{Na}^{+}\right.$ and $\mathrm{K}^{+}$). To characterize the flocculation mechanism of the Kluyveromyces marxianus strain, the effect of these parameters on the flocculation ability of this yeast was tested. Cell wall hydrophobicity measurements were also made to try to correlate this parameter with flocculating capacity.

As far as flocculation ability is concerned, the results obtained for the $\mathrm{pH}$ variation (Table 2)

Table 2

Influence of $\mathrm{pH}$ on the cell surface hydrophobicity and flocculation ability of the flocculent yeast Kluyeromyces marxianus

\begin{tabular}{lll}
\hline $\mathrm{pH}$ & \% Adhesion & $\begin{array}{c}\Delta \mathrm{OD} / \Delta t \\
\left(\mathrm{~min}^{-1}\right)\end{array}$ \\
\hline 3.0 & 11.7 & 0.004 \\
4.0 & 17.9 & 0.007 \\
5.0 & 26.5 & 0.009 \\
6.0 & 8.15 & 0.003 \\
\hline
\end{tabular}


indicate that there is an optimal $\mathrm{pH}$ value close to 5.0 and that flocculation is strongly inhibited for $\mathrm{pH}$ vales lower than 3 and higher than 6 . These results are similar to reported values for several Saccharomyces strains [7].

In this set of experiments, cell wall hydrophobicity values seem to be linearly correlated with flocculation ability. For similar experiments, no changes in cell wall hydrophobicity have been reported for Saccharomyces strains [25].

Anyway, it seems reasonable to accept that if the $\mathrm{H}^{-}$ion concentration is changed in the incubation medium, the hydrophobicity of the cell wall is also modified.

The influence of divalent and monovalent cations on the flocculation ability of $K$. marxianus ATCC 10022 is presented in Table 3.

Taking into account the results obtained for calcium, some conclusions can be drawn.

(1) The time and intensity of mixing during incubation are crucial factors in flocculation. Their effects are, most likely, to increase the collision between cells, resulting in an increase in cell-cell binding.

(2) It is also noticeable that flocculation increases with calcium concentration (in this range of $\mathrm{Ca}^{2+}$ ion concentrations). This effect is more evident for higher agitation systems, indicating the

Table 3

Influence of salts on the cell surface hydrophobicity and flocculation ability of the flocculent yeast cells of Klayeromyces marxianus

\begin{tabular}{lccc}
\hline Salt & Concentration & \% Adhesion & $\begin{array}{c}\text { AOD/At } \\
\left(\mathrm{min}^{-1}\right)\end{array}$ \\
\hline $\mathrm{CaCl}_{2}{ }^{\mathrm{a}}$ & 0 & 24.3 & 0.007 \\
& $5 \mathrm{mM}$ & 26.8 & 0.009 \\
& $10 \mathrm{mM}$ & 18.0 & 0.006 \\
$\mathrm{CaCl}_{2}{ }^{\mathrm{b}}$ & $20 \mathrm{mM}$ & 16.1 & 0.004 \\
& $5 \mathrm{mM}$ & 24.8 & 0.009 \\
& $10 \mathrm{mM}$ & 27.8 & 0.010 \\
$\mathrm{NaCl}$ & $20 \mathrm{mM}^{-1}$ & 34.4 & 0.013 \\
& $50 \mathrm{~g} \mathrm{l}^{-1}$ & 28.0 & 0.010 \\
& $100 \mathrm{~g} \mathrm{l}^{-1}$ & 23.8 & 0.007 \\
\hline
\end{tabular}

a Incubation time, $40 \mathrm{~min}$; agitation rate, $100 \mathrm{rev} \mathrm{min}^{-1}$.

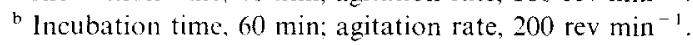

importance of ortokinetic flocculation in the flocculation mechanism.

(3) Once again, flocculation is correlated with cell surface hydrophobicity.

Reported results for Saccharomyces strains indicate no reduction in cell surface hydrophobicity in the presence of calcium [25]. These observations are consistent with the hypothesis presented by Sousa et al. [17] which suggests that the structure and/or spatial arrangement of the groups involved in flocculation are not the same for $K$. marxiamus and $S$. cerevisiae.

As in Saccharomyces strains, the $\mathrm{Na}^{+}$ion has an inhibitory effect on the flocculation ability of K. marxianus. Also, in these experiments, flocculation is linearly correlated with cell wall hydrophobicity.

The influence of sugar concentration on flocculation ability and cell wall hydrophobicity is shown in Table 4.

Only for mannose concentrations higher than $200 \mathrm{mM}$, a significant reduction in the flocculation ability of $K$. marxianus was noticeable. Glucose. in concentrations up to $200 \mathrm{mM}$, seems to have no effect. It is known that Saccharomyces strains possess different sensitivities to sugars regarding flocculation ability [26]. As a consequence, it is not unexpected that a strain belonging to other

Table 4

Influence of sugars on the cell surface hydrophobicity and flocculation ability of the flocculent yeast of Kluyeromyces marxianus

\begin{tabular}{|c|c|c|c|}
\hline Sugar & Concentration & Adhesion & $\begin{array}{l}\text { AOD } 11 \\
\left(\min { }^{1}\right)\end{array}$ \\
\hline \multirow[t]{6}{*}{ Mannose } & 0 & 19.2 & 0.009 \\
\hline & $10 \mathrm{mM}$ & 19.6 & 0.008 \\
\hline & $25 \mathrm{mM}$ & 20.9 & 0.008 \\
\hline & $50 \mathrm{mM}$ & 19.0 & 0.006 \\
\hline & $100 \mathrm{mM}$ & 17.4 & 0.006 \\
\hline & $200 \mathrm{mM}$ & 9.3 & 0.004 \\
\hline \multirow[t]{3}{*}{ Glucose } & $50 \mathrm{mM}$ & 20.1 & 0.009 \\
\hline & $100 \mathrm{mM}$ & 19.8 & 0.009 \\
\hline & $200 \mathrm{mM}$ & 20.0 & 0.009 \\
\hline \multirow[t]{3}{*}{ Lactose } & $50 \mathrm{~g} 1$ & 20.2 & 0.009 \\
\hline & $100 \mathrm{~g}$ & 19.8 & 0.009 \\
\hline & $200 \mathrm{~g} 1$ & 19.8 & 0.009 \\
\hline
\end{tabular}


genera and with some different characteristics in flocculation ability displays this behaviour.

It may be argued that the way that mannose interacts with the cell wall depends on the mannose concentration. These differences may result in different spatial arrangements of the mannose molecule and, ultimately, in changes in the hydrophobicity values.

Lactose was assayed only to confirm that it had no inhibitory effect on flocculation, since the induction of flocculence of $K$. marxianus is carried out in a culture medium containing this sugar.

The treatment of flocculent yeast cells with proteolytic enzymes (Table 5) resulted in the elimination of flocculation ability, as described for several yeast strains, and in a huge decrease in the cell wall hydrophobicity.
Table 5

Influence of pepsin on the cell surface hydrophobicity and flocculation ability of the flocculent yeast of Kluyveromyces marxianus

\begin{tabular}{lcl}
\hline $\begin{array}{l}\text { Incubation time } \\
(\mathrm{min})\end{array}$ & \% Adhesion & $\begin{array}{l}\Delta \mathrm{OD} / \Delta t \\
\left(\mathrm{~min}^{-1}\right)\end{array}$ \\
\hline 10 & 6.2 & 0.0008 \\
30 & 4.5 & - \\
60 & 2.2 & - \\
Control & 19.2 & 0.009 \\
\hline
\end{tabular}

These results suggest that a cell wall protein is involved in the flocculation mechanism of yeasts.

The electrophoretic mobility results act as another confirmation of the role played by cell walls in flocculation. From Fig. 1, it may be

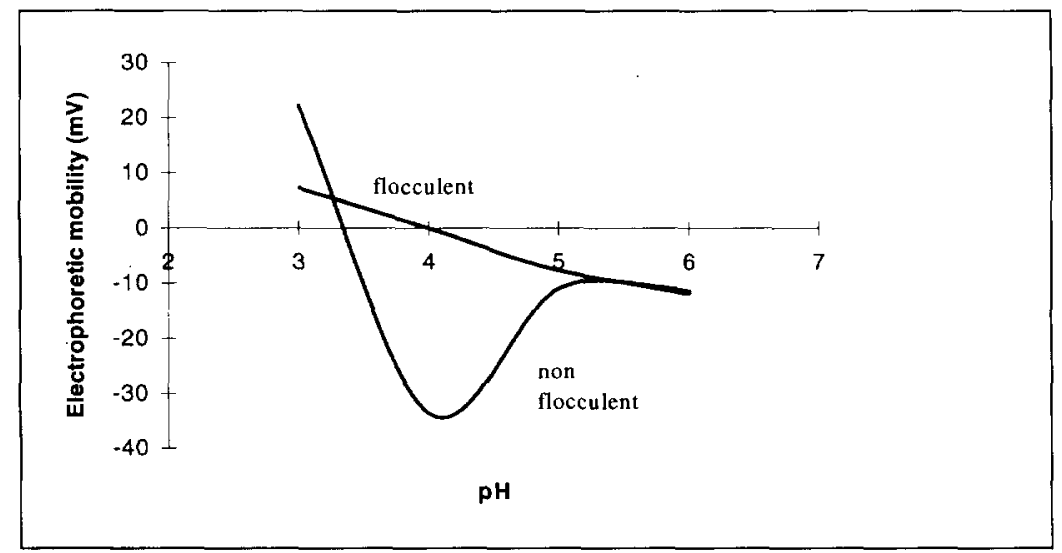

Fig. 1. Electrophoretic mobility of flocculent and non-flocculent cells of Kluyveromyces marxianus as a function of $\mathrm{pH}$.

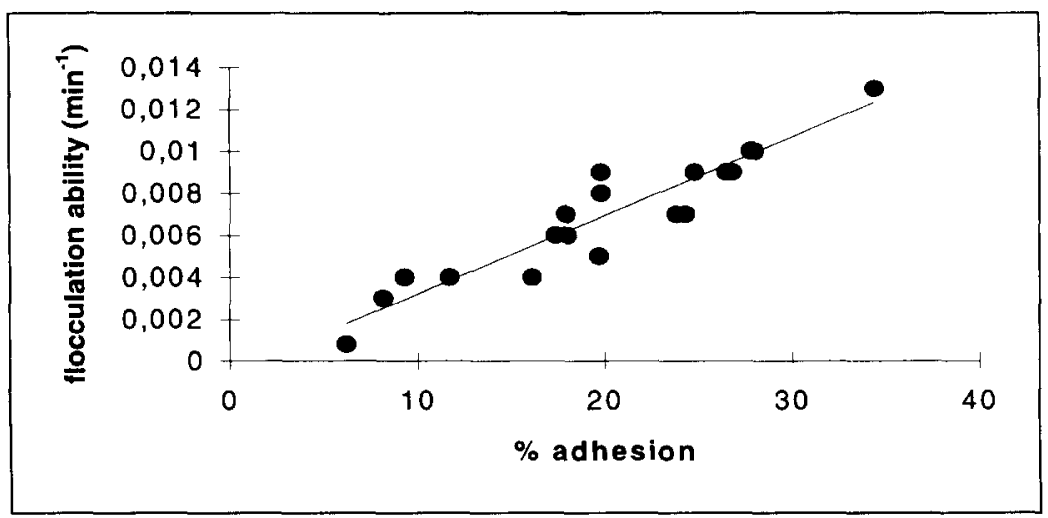

Fig. 2. Correlation between cell wall hydrophobicity of Kluyveromyces marxianus (expressed as the percentage adhesion to hexadecane) and flocculation ability. 
observed that the largest difference between the electrophoretic mobilities of flocculent and nonflocculent cells occurs at $\mathrm{pH}$ values at which the flocculation ability is higher.

It is important to notice that, for all this range of $\mathrm{pH}$ values (and electrophoretic mobility values), cells grown in batch mode are always nonflocculent and their degree of hydrophobicity is always less than $11 \%$ (even at the $\mathrm{p} I$ of these cells). On the other hand, the electrophoretic mobilities of the non-flocculating cells have the same values for $\mathrm{pH}$ between 5 and 6 . If this property were an important factor, the flocculation ability should be similar. This does not happen and the hydrophobicity of the two types of cells is completely different.

As has been pointed out in this discussion, all the results indicate that the flocculation ability of K. marxianus ATCC 10022 and the cell wall hydrophobicity are linearly related. If all the experimental values are gathered and the flocculation ability is plotted vs. cell wall hydrophobicity, a linear relationship (with a correlation coefficient of 0.95 ) is obtained, as is presented in Fig. 2.

This representation clearly indicates that the cell wall hydrophobicity is a major determinant in the flocculation ability of $K$. marxianus flocculent cells.

\section{Acknowledgment}

The authors gratefully acknowledge the financial support of JNICT through the project $\mathrm{PBIC} / \mathrm{C} / \mathrm{BIO} / 1260 / 92$.

\section{References}

[1] G.G. Stewart, I.F. Garrison, T.E. Goring, M. Meleg, P. Pipasts and I. Russel, Kem. Kemi, 10 (1976) $465-479$.
[2] B.L.A. Miki, N.H. Poon, A.P. James and V.L. Seligy J. Bacteriol., 150 (1982) 878-889.

[3] K. Esser, J. Hinrichs and U. Kues, in Y.A. Attia (Ed), Flocculation in Biotechnology and Separation Systems. Elsevier, Amsterdam, 1987, pp. 383-398.

[4] M.A. Amri, R. Bonaly, B. Duteurtre and M. Moll. Eur. J. Appl. Microbiol. Biotechnol., 7 (1979) 235 240.

[5] M. Stratford. Yeast, 5 (1989) 487496

[6] J.C. Kihn, C.L. Masy and M.M. Mestdagh, Can. J. Microbiol., 24 (1988) $773-778$.

[7] G. Smit. M.H. Straver, B.J.J. Lugtenberg and J.W. Kijne, Appl. Environ. Microbiol., 58 (1992) 3709--3714.

[8] E.V. Soares, J.A. Teixeira and M. Mota, Can. J. Microbiol.. 38 (1992) 969-974.

[9] E.V. Soares, J.A. Teixeira and M. Mota. Biotechnol. Lett. 3 (1991) 207-212.

[10] M.H. Straver, P.C. v. d. Aar. G. Smit and J.W. Kijne, Yeast, 9 (1993) 527-532.

[11] M.M. Mestdagh, P.G. Rouxhet and J.P. Dufour, Ferment, February (1990) 31--37.

[12] D.J. Fisher.. J. Inst. Brew. 81 (1975) $107-110$.

[13] G. Moulin and P. Galzy, Biotechnol. Genetic Eng. Rev., 1 (1984), 347-374.

[14] J.A. Teixeira, M. Mota and G. Goma, Bioprocess Eng., $5(1990) 123-127$.

[15] J.A. Teixeira, M.H. Gonçalves, F.M. Gama, P. MoradasFerreira and M. Mota, Biotechnol. Lett.. 11 (1989) $579-582$.

[16] P.A. Fernandes. J.N. Keen, J.B.C. Findley and P. Moradas-Ferreira, Biochim. Biophys. Acta, 1159 (1992) 67.73.

[17] M.J. Sousa. J.A. Teixeira and M. Mota. Biotechnol. Lett., 14 (1992) 213218.

[18] M. Mota and J.A. Teixeira, Current Microbiol, 20) (1990) 209-214.

[19] M. Rosenberg, FEMS Microb. Lett., 22 (1984) 289-295.

[20] D.F. Gerson, Biochim. Biophys. Acta, 602 ( 1980$) 269$ - 280 .

[21] W.B. Clark, M.D. Lane, E. Beem, S.L. Bragg and T.T. Wheeler, Infect. Immun., 47 (1985) 730-7.36.

[22] H.J. Busscher, A.H. Weerkamp, H.C. van der Mei. A.W.J. van Pelt, H.P. De Jong and J. Arends, Appl. Environ. Microbiol., 48 (1984) 980 983.

[23] N. Mozes, L.L. Schinkus, C. Ghommidh, J.M. Navarro and P.G. Rouxhet, Colloids Surfaces B: Biointerfaces. 3 (1994) 6374

[24] H.C. van der Mei, A.H. Weerkamp and H.J. Busscher, J. Microbiol. Methods, 6 (1987) 277-287.

[25] M. Straver. Ph. D. Thesis, University of Leiden, 1993.

[26] C.L. Masy. A. Henquinet and M.M. Mestdagh, Can. J. Microbiol., $38(1992) 1298 \cdots 1306$. 